\title{
INCIDENCE OF RICKET CLINICAL SYMPTOMS AND RELATION BETWEEN CLINICAL AND LABORATORY FINDINGS IN INFANTS
}

\section{AUTHORS}

Čukalović M., Krdžić-Milovanović J., Odalović A., Jakšić D. Children's clinic, Medical Faculty Pristina, Kosovska Mitrovica

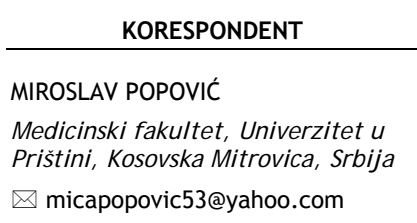

KORESPONDENT

Medicinski fakultet, Univerzitet u Prištini, Kosovska Mitrovica, Srbija

$\triangle$ micapopovic53@yahoo.com

\section{SUMMARY}

Rickets presents osteomalacia which is developed due to negative balance of calcium and / or phosphorus during growth and development. Therefore it appears only in children. The most common reason of insufficient mineralization is deficiency of vitamin D, which is necessary for inclusion of calcium in cartilage and bones. As result, proliferation of cartilage and bone tissue appears, creating calluses on typical places. Bones become soft and curve, resulting in deformities. Our present study included 86 infants, in whom, besides other diseases, clinical and laboratory signs of rickets were identified. In our study, rickets is most common (82.5\%) in infants older than 6 months. By clinical picture, craniotabes is present in $46.5 \%$ of cases, Harisson groove in $26.7 \%$, rachitic bracelets in $17.4 \%$, rachitic rosary in $17.4 \%$ and carpopedal spasms in $2.3 \%$ of cases. Leading biochemical signs of vitamin D deficient rickets is hypophosphatemia (in $87.3 \%$ of cases), normal calcemia (in 75.6\% of cases) and increased values of alkaline phosphatase (in $93 \%$ of cases). It has been shown that rickets in infant age may later affect higher incidence of juvenile diabetes, infection of lower respiratory tract, osteoporosis, and so on.

Keywords: rickets, children, vitamin D.

\section{INTRODUCTION}

Rickets is bone disease which leads to improper bone development in children due to insufficient mineralization [1,2]. It is a multisystem disease with predominantly bone lesions. Osteogenesis is a complicated and dynamic complex of events in which calcium and phosphorus metabolism has a dominant role. These two elements are required for the construction of hydroxyapatite, which is deposited in the osteoid tissue and provides necessary rigidity for bones. The basic condition for normal homeostasis of calcium and phosphorus is optimal activity of the main metabolite of vitamin D (25-hidroxycalciferol and 1,25-hidrooxycalciferol) of parathyroid hormone (PTH), calcitonin and intact function of digestive system and kidneys. Presence of PTH is necessary for conversion of $25(\mathrm{OH}) \mathrm{D}$ to $1,25(\mathrm{OH}) 2 \mathrm{D}$. Vitamin $\mathrm{D}$ needs are fulfilled through endogenous synthesis and food intake. Daily needs of vitamin D during growth and development period are $400 \mathrm{IU}$. Vitamin D amounts in food, especially in milk, are insufficient, so majority of physiological needs for this micronutrient is gained from photolysis of 7-dehydro-cholesterol in skin exposed to ultraviolet rays [3]. Among innfants who live in areas with temperate and cold climate, and are not exposed to sunlight whole year, vitamin $D$ production is often insufficient and does not satisfy needs of the organism, so in past these children often contracted rickets. Provitamin $\mathrm{D}$ is produced in liver from cholesterol and is deposited in the skin. Since the normal diet has a sufficient amount of calcium and phosphorus, pathogenesis of rickets is most often based on insufficient interstitial absorption of these two elements as a result of deficit in vitamin $D$ and its metabolites [4].

\section{Image 1. Craniotabes}

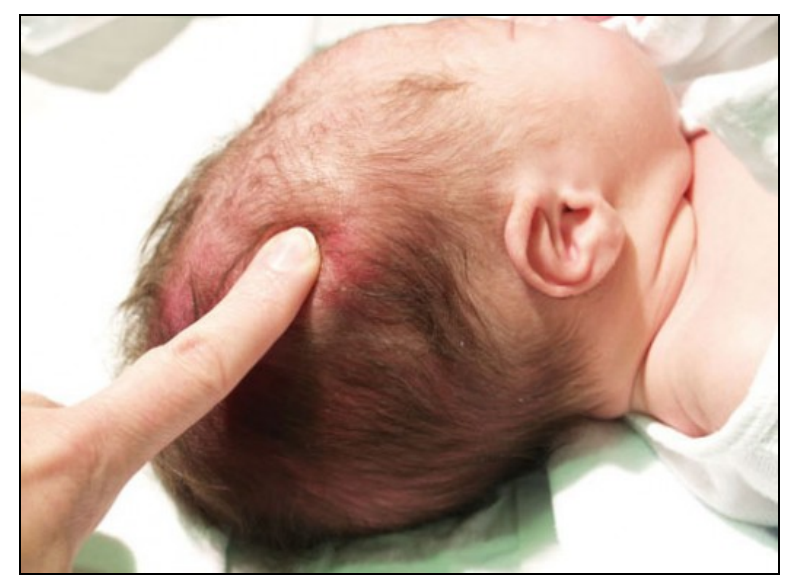

In a rare clinical pictures, rickets develops as primary consequence of pathological loss of calcium and phosphorus through kidney. In clinical practice, the most often type of rickets is vitamin D deficient rickets, which is diagnosed in infants in second half of first year of life. Phosphatase rickets is rarer, and is consequence of excessive loss of phosphates through kidney, which is usu- 
ally hereditary disease. Important part of vitamin D deficiency rickets pathogenesis is insufficient photolysis of 7dehydro-cholecterol and a diet that favors malabsorption of calcium. This rickets type is more often in children with a darker skin tone, with insufficient sun exposure and in case of diet with unmodified cow's milk or diet with superabundance of grain intake. In our environment, cases of neonatal (congenital) rickets, due to vitamin D deficiency and osteomalacia through pregnancy, is not present. Rickets of premature infants is primarily caused by inadequate intake and by insufficient intestinal absorption of calcium and phosphorus due to immaturity, while resorption and activation of vitamin $D$ remain intact. Vitamin D deficient rickets is rare in older children, primarily because of sufficient sunlight exposure, complete nutrition and lower growth rate [5].

Image 2. Rachitic rosary

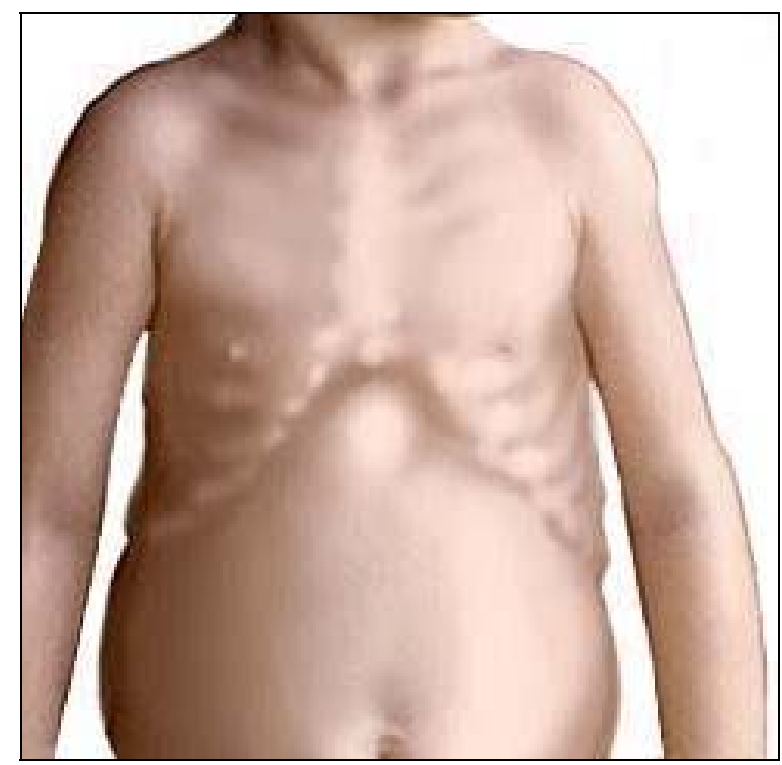

Image 3. Rachitic bracelets

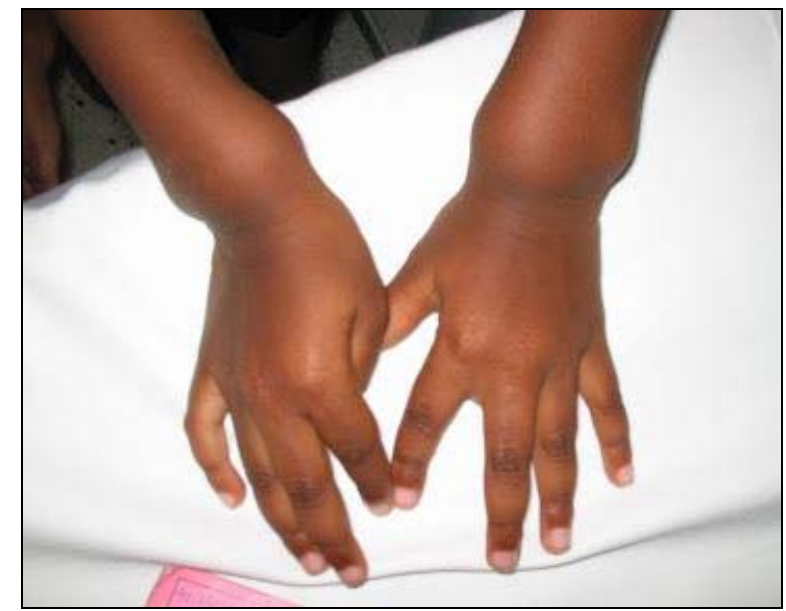

Clinical picture of rickets is dominated by characteristic bone deformities as a result of osteomalacia and hyperplasia of osteiod tissue. The most often visible change is behavioral change with sweating, craniotabes, Harisson groove, rachitic rosary, rachitic bracelets and carpopedal spasms.
Reliable diagnosis of rickets can be set only if, at the same time, there are clincal, laboratory and radiographic signs of disease. Diagnosis is based on characteristic clinical findings and determination of calcemia, phosphatemia and alkaline phosphatase concentration, as well as the findings of $x$-ray that confirms bone changes.

Sufficient intake of vitamin $D$ and adequate physical activity during growth period, from first year to end of adolescency, are only real prevention for this significant problem in children [6]. This problem may be cause of severe osteophorosis in adulthood, whose treatment is expensive and uncertain.

\section{THE AIM}

The aim of this paper is to point to frequency of clinical symptoms and the relationship between clinical and laboratory findings of rachitic infants, as well as the importance of vitamin D prophylaxis implementation.

\section{MATERIAL AND METHODS}

The retrospective analysis included 86 infants hospitalized in the pediatric department of KBC Gracanica due to other diseases, that were diagnosed rickets based on clinical and laboratory findings. Medical history, clinical findings, laboratory tests (values of calcium, phosphorus and alkaline phosphatase) and skeletal radiography were used for diagnosis.

\section{RESULTS}

The survey was conducted on group of 86 children, aged 0 to 12 months. Analysis of patients by age showed that signs of rickets usually occur between the ages of 6 months onwards (in $70,9 \%$ of cases), while the distribution of respondents by gender shows representation of males of $60,5 \%$, and females $31,5 \%$.

Table 1. Incidence by age and sex

\begin{tabular}{ccc}
\hline Age & $\mathbf{n}$ & $\%$ \\
\hline $2-3$ months & 5 & 5,8 \\
\hline $3-4$ months & 10 & 11,6 \\
\hline $5-6$ months & 10 & 11,6 \\
\hline $7-9$ months & 36 & 41,9 \\
\hline $10-12$ months & 25 & 29 \\
\hline
\end{tabular}

\begin{tabular}{ccc}
\hline Sex & $\mathbf{n}$ & $\%$ \\
\hline Male & 52 & 60,5 \\
\hline Female & 34 & 39,5
\end{tabular}

Regarding clynical symptoms, in $46.5 \%$ of cases craniotubes was diagnosed, most often in age of 5 - 6 months (50\%). In $40,7 \%$ of cases behavioral change and sweating was diagnosed, most often in age 3 - 4 months $(80 \%)$. In $26,7 \%$ of cases Harisson groove was diagnosed, most often in age of 5 - 6 months $(43,5 \%)$. In $17,4 \%$ of cases rachitic bracelets was diagnosed, most often in age of 7 - 9 months $(66,7 \%)$. In same incidence $(17,4 \%)$, rachitic rosary was diagnosed, most often in age of $5-6$ months $(53,3 \%)$. In only $2,3 \%$ of cases carpopedal spasms were diagnosed, and only in age of $10-12$ months.

Leading biochemical signs of vitamin $\mathrm{D}$ deficient ricket were represented in $75,6 \%$ normocalcemia, in $24,4 \%$ hypocalcemia, in $12,7 \%$ normophosphotamia and in $87,3 \%$ hypophophotamia. Increased values of alkaline phosphatase were represented in $93 \%$ of cases. 
Tabela 2. Incidence of rickets clinical symptoms by age

\begin{tabular}{|c|c|c|c|c|c|c|c|c|c|c|c|c|}
\hline \multirow[t]{2}{*}{ Age } & \multicolumn{2}{|c|}{$\begin{array}{l}\text { Behavioral } \\
\text { change and } \\
\text { sweating }\end{array}$} & \multicolumn{2}{|c|}{ Craniotubes } & \multicolumn{2}{|c|}{$\begin{array}{l}\text { Harisson } \\
\text { groove }\end{array}$} & \multicolumn{2}{|c|}{$\begin{array}{c}\text { Rachitic } \\
\text { bracelets }\end{array}$} & \multicolumn{2}{|c|}{ Rachitic rosary } & \multicolumn{2}{|c|}{$\begin{array}{c}\text { Carpopedal } \\
\text { spasms }\end{array}$} \\
\hline & $\mathrm{n}$ & $\%$ & $\mathrm{n}$ & $\%$ & $\mathrm{n}$ & $\%$ & $\mathrm{n}$ & $\%$ & $\mathrm{n}$ & $\%$ & $\mathrm{n}$ & $\%$ \\
\hline 2 - 3 months & 2 & $5,7 \%$ & 5 & $12,5 \%$ & 0 & $0,0 \%$ & 0 & $0,0 \%$ & 0 & $0,0 \%$ & 0 & $0,0 \%$ \\
\hline $3-4$ months & 28 & $80,0 \%$ & 15 & $37,5 \%$ & $\overline{0}$ & $0,0 \%$ & 0 & $0,0 \%$ & $\overline{0}$ & $0,0 \%$ & 0 & $0,0 \%$ \\
\hline $5-6$ months & 5 & $14,28 \%$ & 20 & $50,0 \%$ & 10 & $43,5 \%$ & 0 & $0,0 \%$ & 8 & $53,3 \%$ & 0 & $0,0 \%$ \\
\hline $7-9$ months & 0 & $0,0 \%$ & 0 & $0,0 \%$ & 8 & $34,8 \%$ & 10 & $66,7 \%$ & 2 & $13,3 \%$ & 0 & $0,0 \%$ \\
\hline $10-12$ months & 0 & $0,0 \%$ & $0^{-}$ & $0,0 \%$ & 5 & $21,7 \%$ & 5 & $33,3 \%$ & 5 & $33,3 \%$ & 2 & $100,0 \%$ \\
\hline Totàl & $3 \overline{5}$ & $40,7 \%$ & $40^{-}$ & $46,5 \%$ & 23 & $26,7 \%$ & 15 & $17,4 \%$ & 15 & $17,4 \%$ & 2 & $2,3 \%$ \\
\hline
\end{tabular}

Table 3: Calcemia, phosphotamia and alkaline phosphatase values in examined infants

\begin{tabular}{|c|c|c|c|}
\hline Signs & Value & $\mathrm{n}$ & $\%$ \\
\hline & Hypocalcemia & 21 & $24,40 \%$ \\
\hline Calcemia & Normal calcemia & 65 & $75,60 \%$ \\
\hline Phosphotamia & Hypophosphotamia & 75 & $87,30 \%$ \\
\hline Pnospnotamia & Normophosphatamia & 11 & $12,70 \%$ \\
\hline Alkaline phosphatase & Increased values & 80 & $93,00 \%$ \\
\hline
\end{tabular}

Vitamin D prophylaxis was conducted in $65,1 \%$ of infants, although even then children rarely received doses regularly and in optimal amount.

\section{DISCUSION}

Rickets occupies an important place in pathology of children in early age. Numerous statistics show different frequencies of disease. In early 20th century, rickets become major public health problem of industrial cities in Europe and America. It is disease of the whole organism due to disorder in metabolism of calcium and phosphorus, and is bound to deficiency of vitamin D. Although is rickets disease of different organs (muscles, lungs, nervous system), it is primarily disease of the skeleton, and that is main point of interest for us [7]. In our country, most common and widespread type is vitamin $D$ deficient rickets. Even today, in some areas presents social disease, and only if understood so can lead to proper prophylaxis. Any hypothesis to explain rickets should explain a few unquestionable facts: time of ricket occurence coincides with a period of maximum and intense growth, bone lesions which are especially affecting metaphysary zones of active bone growth and biologicaly variable syndroms such as calcemia and phosphatemia. Term „variability" is one ot the proof for the complexity of the rickets mechanisms. If we take only vitamin D deficiency and its impact on bone development, we wouldn't understand why children of given age, in same enviromental conditions, who haven't been taking vitamin D, don't have bone lessions and roughly the same biological disorders [5, 8]. The difference is huge. Some will have minimal radiological changes, other will have demineralised and disorted skeleton, some will be hypocalcemic, while other won't be. Futhremore, some children will be rachitic, others won't. We must accept that other etiological factors contributes to rickets being polymorphic and having varying degrees of intensity.

In addition to the deficiency of vitamin D, as important etiological factor, many other constitutinal and enviromental factors contribute to various aspects of rickets [9]. In most traditional textbooks differences be- tween clinical presentation of vitamin D deficiency depending of age at which first symptoms appear are emphasized [10]. Such divisions have more didactic importance, as sharp boundaries between certain types of vitamin $D$ deficient rickets cannot be drawn.

The research included 86 infants with signs of rickets. Highest incidence of rickets $(70.9 \%)$ were in children older than 6 months. Male children shows signs or rickets earlier. The changes are usually observed at the head craniotubes are most often symptom, in $46.5 \%$ of cases, as consequence of osteomalacia and hyperplasia of osteoid tissue. Other common symptoms are rachitic rosaries $(17.4 \%)$, which are consequence of osteoid thickening on crossing between cargtilage and bone in ribs, rachitic bracelets $(17.4 \%)$, behavioral changes (irritability or reduced interest for enviroment) and sweating (40.7\%), carpopedal spasms $(2.3 \%)$.

Normocalcemia was found in $75.6 \%$ of cases, hypophosphatemia in $87.3 \%$ and increased values of alkaline phosphatase in $93.0 \%$ of cases.

Due to adequate therapy, vitamin $D$ deficient rickets is rarely seen today in our society.

\section{CONCLUSION}

Our observations lead to conclusion that problem of vitamin $D$ deficient rickets is still present in today pediatric practice. For proper early diagnosis of rickets full attention should be given to the symptoms that are more or less characteristic for this disease, as well as laboratory testing, primarily alkaline phosphatase in serum and values of calcium and phosphate, in order to timely apply appropriate therapy. Concern for children's health contribute to sucsessfull raising of future healthy generations. 


\section{REFERENCES}

1. John Jacob Cannell, Magnesium and vitamin D's co-factors, citing The Lancet; The vitamin D Council, 2009; 126:45-12

2. The Free Dictionary - rickets. In turn citing: The American Heritage Medical Dictionary and Mosby's Dental Dictionary, 2nd edition, 2008

3. Barr Sharma, Macdonalds H.M, Sheeny T, Novotny R, Corriveau A. Vitamin D deficiency and disease risk among aboriginal arctic populations. Nutritional Review, 69(8): 468-478, 2011.

4. Stepanović R. Pedijatrija, 10. izmenjeno izdanje, Savremena administracija a.d., Beograd, 2001:204-208.

5. Nield LS, Mahajan P, Joshi A, Kamat D. Rickets: Not a Disease of the past. American Family Physician, 2006.

6. James Meschino. Complete guide to vitamin D, Meschino Health, 2012.

7. Balasubramanian S, Ganesh R. Vitamin D defficiency in exclusively breast-fed infants. Indian J Med Res 127, 2007, $250-255$.

8. Guyton A.C, Hall J.E. Medicinska fiziologija. Medicinska naklada, Zagreb, 1999.

9. Pettifor J.M. Vitamin D or calcium defficiency rickets in infants \& children: a global perspective. Indian J Med Res 127, 2012, 245-249.

10. Greenbaum L.A. Rickets and Hypervitaminosis D in Nelson Textbook of Pediatrics, 18th Edition. Elsevier, Philadelphia, USA, 2007: 253-262.

\section{SRPSKI}

\section{UČESTALOST KLINIČKIH SIMPTOMA RAHITISA I ODNOS IZMEĐU KLINIČKIH I LABORATORIJSKIH NALAZA U ODOJČADI}

Čukalović M., Krdžić-Milovanović J., Odalović A., Jakšić D.

Dečja klinika, Medicinski fakultet Priština, Kosovska Mitrovica

\section{SAŽETAK}

Pod rahitisom se podrazumeva osteomalacija koja nastaje kao posledica negativnog bilansa kalcijuma i/ili fosfora tokom perioda rasta i razvoja. Zato se javlja samo kod dece. Najčešći razlog nedovoljne mineralizacije jeste nedostatak vitamina D neophodnog za ugradnju kalcijuma u hrskavice i kosti i kao posledica javlja se bujanje hrskavičavog i koštanog tkiva, što stvara zadebljanja na tipičnim mestima, kosti postaju meke, krve se i tako nastaju deformiteti. Naše istraživanje obuhvatilo je 86 odojčadi, kod kojih su pored drugih oboljenja utvrđeni i klinički i laboratorijski znaci rahitisa. U našem istraživanju, rahitis se najčešće u (82,5\%) sreće kod odojčadi starije od 6 meseci. U kliničkoj slici, craniotabes je zastupljen u 46,5\% ispitanika, Harissonova brazda u 26,7\% , rahitične narukvice u 17,4\%, rahitične brojanice u 17,4\% i karpo-predalni spazmi u 2,3\% slučajeva. Vodeći biohemijski znaci u vitamin D - deficijentnog rahitisa su: normokalcemija $75,6 \%$, hipofosfotemija $87,3 \%$, a povećane vrednosti alkalne fosfataze $93,0 \%$ ispitanika. Pokazalo se da rahitis u odojačkoj dobi, kasnije može uticati na veću pojavu infekcija donjih disajnih puteva, juvenilni dijabetes, osteoporozu itd.

Ključne reči: rahitis, vitamin $D$, odojče. 